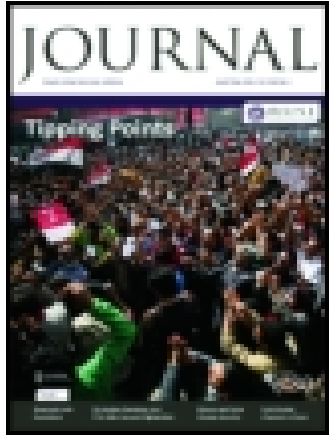

Royal United Services Institution. Journal

\title{
Preservation of Biscuit and other Farinaceous Articles of Diet from Weevil, Maggots, and other Insects in H.M. Navy
}

\section{W. E. Seccombe Esq.}

To cite this article: W. E. Seccombe Esq. (1875) Preservation of Biscuit and other Farinaceous Articles of Diet from Weevil, Maggots, and other Insects in H.M. Navy, Royal United Services Institution. Journal, 19:83, 681-688, DOI: 10.1080/03071847509415780

To link to this article: http://dx.doi.org/10.1080/03071847509415780

曲 Published online: 11 Sep 2009.

Submit your article to this journal $₫$

Џ Article views: 5

Q View related articles ¿ 


\section{PRESERVATION OF BISCUIT AND OTHER FARINACEOUS ARTICLES OF DIEI FROM WEEVIL, MIAGGOTS, AND OTHEI INSECTS IN H.M. NAVY.}

Communicated by W. E. Seccosine, Isq., Controller's Department, Admiralty.

I XEED scarcely say that for a very long period it las been found that tho biscuit on board H.M. ships, when in a hot and tropical climate, has been rapidly attacked and destroyed by weevils and maggots, of ten to such an extent as to render it vers repulsive, and quito unfit for human food, sometimes causing large quantities of it to be thrown orerboard, or otherwise returned to the victualling fards when the vessel arrives in England.

This damaged and morm-eaten biscuit has usually been sold by auction from time to time, as it has accumulated, for fecding cattle, \&c.

After the commencement of the annual sales, about four or five years since, tho largo quantity of biscuit which camo to the liammer, as well as the worm-eaten condition in which some of it mas found, attracted the special attention of the officials at the Admiralty, and it was considered desirable that some arrangement should be made to prevent so great a sacrifice of the very first-class biscuit, which is regularly manufactured at cach of the victaalling sards.

Having had the honour of being deputed by the authorities at the Admiralty to attend at these sales, I thought it was possible to stow the biscuit in iron tanks, hermetically closed, in such a manner as to make each tank in the bread-room easy of access; and at the same time to be so closely stowed in tho ressel as to carry the full complement of bread for the ship's company as if it had been filled in bags in the usual way.

Having been requested to state the proposed mode of fitting the tanks, a rough sketch showing tho form of scuttles for filling and emptying, \&c., was forwarded, which obtained the approval of the proper anthoritics, and it was determined that three trial-tanks should be prepared at Deptford Yard (similar to sketch B), which should bo filled with biscuit at Deptford, Plymouth, and Gosport Victualling Yards; respectively, and hermetically closed for twelve months, in 
order to test the condition of the biscuit after being kept closely confund for tho time named.
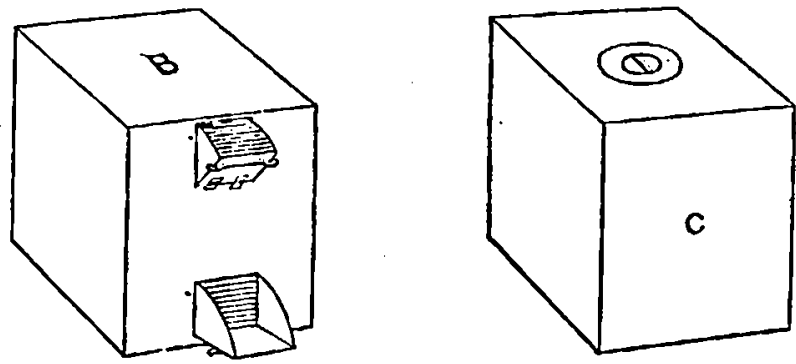

It mas be observed that biscuit had been on sercral previous ocensions put into iron tanks on board ships and in the storerooms at different stations; but, as a rule, it had milderred and got spoiled, or lind becomo infested with insects, which mado some of the persons, who had considerable experience in these matters, somem hat fearful of the satisfactory results of the experiments about to be made; but the tanks formerly used mero simply the old water-tanks with tho manhole at the top, which necessitated the sending some one into the tank from time to time to get out the bread, which operation is, in itself, rerg disagrecable to persons eating the bread, whilo the constant opening and shut. ting the manlole (sce sketch C), which is on the top of the tank, allowed aing water falling on the tank to get into it, and the corer not being hermetically closed (and perhaps sometimes left off altogether) allowed the weevil to penetrate, and thus spoil the rhole of tho bread.

The arrangements of the fittings in the proposed experimental tanks were as follows :- Sketch A shows the upper scuttle for filling, and tho

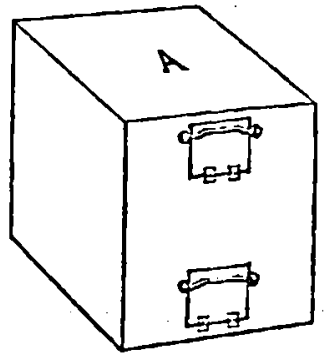

lower one for emptying, closed up and scremed tightly. The upper scuttle turns down to an angle of $45^{\circ}$ with side flaps turning up (as shorn in sketch B), the biscuit falling naturnlly out of the mouth of the bag into the tank. The lower scuttle, as will be.scen, falls down level, and the biscuit is drawn out with a small rake into bags as re. quired, the whole contents of the tank falling dorrn naturally until most 
of the upper part of tho tank is cmptied, when that at tho bottom is diann out by the arao as before. When about to fill the tank, the bottom scuttle is first screwed lrome tightly and joint putticd up, liko the mode of securing an ordiuary pane of glass, and after all the bread is put in, tho upper scuttle is closed and hermetically sealed in like manner; and, in taking out tho bread, it is only necessary to clean out the putty, turn down the lower lid, and take out what is required, when the lid must be again tumed up, screved home, and re-puttied.

The inside of the tanks is conted orer with hot lime-wash, fired with about threc-quarters of a pound of coarso sugar to each gallon of wash, which kceps the lime from corning off and forms a good wholesomo conting.

As beforo stated, the three experimental tanks, when completed, werc cxamined, and approved by the Constmuctor's' Department and Superintendent of Victualling. One of the tanks was retained at Deptford, and tho others sent to Deronport nud Gosport Victualling Yards, where they were filled with tho newest bread that could bo obtained, and hermetically closed up (as beforo described), in the prescnco of tho Officers of the jard, the breat being carefully woighed before being put in, and a record kept of the weight.

The tank at Deptford, as well as the ono at Deronport, was filled with biscuit only about two or three days old, lut at Gosport the newest biscuit in storo was several weeks old, which was accordingly put into that tank.

The tanks were filled in the summer of 1971 , when the moth and weeril were very plentiful, and the experimental tanks were put into the condemned bread store, where largo quantities of infected biscuit were stowed in bag:s, the weevil, moths, and maggots abounding at that season all orer the loft, and crawling in aud out of the open pores of the biscuit bags, which were kept stored there, as it arrived from the ships, in order to await the annual sale.

If therefore (as somo parties stated) tho reerils, maggots, \&c., bred naturally in tho biscuit when stowed in closed iron cases at a high temperature, there was every opportunity for their so doing in the tanks during tho summer wentler, but if (as scems most reasonable) tho moths and weevils fly about from place to place, and deposit their numerous eggs in the bags of new bread, thes have amplo opportunity for so doing, as in the store lofts, where the bags of new lorend are stowed, the windows are usually open for rentilation, and these insects can fly in or out at pleasure, as they undoubtedly do, and thus corrupt, in a short time, the good bread. This was elcirly to be seen in opening the Gosport tank, after the trrelre months harl expired, for; whilo the tanks at Deptford and Devonport, when opened, had not the slightest sign of insect life (the biscuit with which they wero filled being all fresh baked), that at Gosport, whero tice bread had been lying in bags for some weeks before being put into the tank; showed very clear indications of maggots hariug crawled orer the biscuit, and sereral liro maggots were found, although they scence in a weak condition, and had in no instanco bored into the biscuit. It was, however, very manifest that, for lack of air, the maggots had 
not in any case changed into the chrysalis state, nor were there any moths risible, which shows that there is no danger of further propa. gation, even if the joung maggots are formed, after the tanks are hermetically sealed.

I would also obserse that at the time of filling the tanks at the Royal William Victualling Yard, Deronport, I took an opportunity of putting, into largo tin cases, some of the reevilly biscuit in rhich were lundreds of these living insects in different stages of existence, also I took from the vindows, where the live weerils were crawling and flying albout in largo numbers, some scores of them and placed them in amoug the others, putting in a quantity of sound liscuit for them to subsist on, and then hermetically closed them up; on re. moring the lid of these tin cases after being closed twelre months, not one of the reerils mas alive, and it would appear that they had not lived long after being closed up, for tho meevilly biscnit sliowed no signs of being moro full of holes than when put into the tin, whilo the : sound biscuit was perfectly freo from their mrages, as when first put in, plaiuly showing that weevils will not live if shut in from the air, so that if new biscuit is slightiy affected with weevil, if, at once, it is hermetically closed np, it prevents the further injury of the biscuit. It must, howorer, be carefully arranged to hare the biscuit perfectly drs, and thus ensure its freedom from milder, which is sure to take place if the bread gets damp from any accidental cause before it gets into the tank, but once in the tank, howerer damp the external atmosphere from foggy or met weather, steam, dec., it will be perfectly free from its influence, and come out lighter than when it went in; this was specially manifest in all the experimental tanks, where the bread weighed about one per cent. lighter than when it was put in.

I would also remark that in the erent of a ressel shipping a sen, or of a fire occurring on board requiring water to be largely thrown about, in the ricinity of the bread rooms, when, from spoke or steam, or both combined, the bread, if stored in bags, would be sure to be spoiled, the tanks rould effectually kecp it safe from injury, except the fire were so ficree as not to be got under; also, if fire should occur, and only a rery short time be available for getting out prorisions into the boats, one of the iron cases, or smaller tanks mar without ceremons be pitched overboard, or, if time permit, be loviered with a rope, as the cases would smim, and the biscuits be taken out at leisure, or the "cases" mas be stowed awas in the boats, where it could be kept dry for use, however rough tho weather may be.

$\Lambda$ the time of the opening of the experimental tanks in the presence of the Oflicers of the yard, a sample of the biseuit was sent to the Admiralty with an elaborate report, which on the whole was cousidered to be so satisfnetory that it was determined to fit out one ressel of each class with these tanks.

It was, however, afterwards considered that some of the smaller class ressels going out to trupieal stations wonld be the best test, and accordingly the "Dait," 570 tons, was so fitted and sailed to the south-east const of America, in Junc, 187:; nest came t'se "Frolic," 
592 tous, composite gun boat, fitted at Chatham, which went to China, on her first commission, carly in Hebruary, 1873, afterwards t!le "Amethyst" corvette of 1,405 tous, was so fitted at Derouport; also on her first commission, this vessel went to the south-east coast of America and West Coast of Africa, alout Mugust, 1873, and listly came the "Victor Lmanuel," of 3,087 tons, which was fitted at Portsmouth as a hospital ship for the troops, which went out to the Ashantee war, her tanks, $16 \mathrm{in}$ number, contained 20,000 llbs. of biscuit. She sailed for the seat of war on the West Coast of Africa, in November, 1873. Other vessels are now in course of being fitted, viz., "Uudaunted," frigate, " Diamond," and "Sapplire," corvettes, also "Juno," and "Volverine," while other vessels are being considered which are intended for the reliefs on foreign stations during the next year.

Satisfactory reports have been reccired from each of the vessels, as to the condition of the biscuit. The captains of the ships were directed to forward a detailed account of where it was obtained, the date when each of the tanks was filled, and when enptied, together with the condilion of the bread on these occasions; the report to be forwarded to their Jordships every six months during the commission.

'The first report from Commander Denny, Her Majesty's ship, "Dart," of 22nd May, 1873, after about cleven montlis' trial, stated " that the biscuit was good, drs, and free from weevil, almost as good "as when putiuto the tanks." "The second report from "Dart," 2jth May, 1874, said "that the service bread stowed in tanks was very" "good. What was obtained from contractor good, in some cascs, but " in others attacked by mildew, but yet better than if kept in bags." I may here observe that the remarks respecting the bread obtained from contractors on foreign stations is quite in kecping with the general experience of Oflicers commanding Iler MIajesty's ships, respecting the use of this sort of biscuit which is often made of inferior flour, or adulterated with pea-meal, and other deleterious ingredients, added to which it is not dessicated in the very satisfactory manner in which our service biscuit is prepared, and hence the great difficulty experienced in preserving this bread; the proposed remedy for this will be treated further on.

The first report from Commander Buckle, Her MIajesty's ship "Frolic," China station, 30th June, 18t3, stated that "the iron cases " keep the bread in excellent preservation and entirely free from damp " and decay, not the slightest sign of maggot or weevil having jet " been obserred," but report also stated that tanks fitted with lids for "filling and emptying were best, as the experimental potato cases "were too slight and got broken, and had to be thrown overboard."

The second report from "Frolic," dated 31st December, 1873, stated that these cases beep the biscuit in excellent condition, not the slightest sign of decay or wecril has been discovered in any of the biscuit so protected; biscuit which has been eleren montlis in the ship is as good as when put on board. Mention is also again made of the slight material of which potato cases were made, advising their being not quite filled in future, in order to prerent their bulging out, VOL. XIX. 
also adrising that only half tho bread-room may bo filled with cases. This last recommendation, however, is considered not advisable, as it would necessitate about six weeks stock being put into bags, which is double the quantity that is decmed safe so to dispose of, as tho weevil, in two or three weehs, in a tropical climate, has been known to get ? large hold on the bags of bread exposed to their ravages. A report was receired at the Admiralty from "Amethyst," dated 30th Juue, 1874, stating that the bread.room fitted with hermetically sealed iron tanks, has answered well, and the bread appears to kecp in better condi. tion than when stowed in bags in tho ordinary manner. A second report from tho "Amethyst," was reccived after more than twelve months" trial; which stated that " the plan has hitherto answered very well, "the biscuit receired in England being as good now as when put on " board." A remark was also apjended, "that the process of filling the "tanks occupies more time than stowing bread in the ordinary way." This, of course, must of necessity be the case, but is of little moment compared with tho adrantages of the ship's company being constantly supplied with perfectly smect and wholesomo bread.

A report from Captain Parkin, IIer Mnjesty's slip "Pictor Emanuel," dated Hong Kong, 30th Norcmber, 1874, arrived at the Admimlty" carly in the present Jear, which said that "the tanks have been most " snccessful in preserving the biscuit, notwithstanding the heat and " closeness of the atmospliere at Cape Coast Castle, and the various " temperatures passed through daing tho passage to China, the "biscuit cane out as fresh and sweet as when weceived from the "victualling yard, and perfectly free from insects. The tanks hare "been renoved from the ship, and will be used for storing brend at "Hong Kong Victualling Yard. The reason why the tanks have been " removed is, that the vessel is brought near tho jetty, and soft bread " will be ased while sho remains in that position."

The Paymaster's report from "Victor Emanuel" is to this effect :: The biscuit was as fresh and sweet as when received from the "victualling yard, not the sign of the reeril or any inscets. I "consider tho tanks an excellent arrangement for preserving tho "biscuit."

It therefore appears clear that, if hiscuit thoroughly desiccated as that is which is so well mannfactured in our victualling yards, is put into tanks and hermetically closed, even in the hurried manner in which that was got on board for tho Ashantec expedition, it is perfectly safe from harm, cither from heat or moistare; as when the joints of the scuttles are puttied, they are quite water-tight as well as air-tight. Bad smells, therefore, arising from exlalations from bilgo water, or other causes on board ship, will not affect the biscait in any was, neither are those pests of a warm climate-the cockmaches-able to get anything to fecd on, as they constantly have when the bread is kept in bags, and they are, therefore, far less likely to proparate. And cren in our more temperate climate, where the weeril is seldom secn, it would seem very desirable that the bread should be put into tanks, because tho raviges of rats and mice in tho open brend-room, when the biscuit is stowed in bags, is something very considerable, and canses large quantities of 
it to be annually thrown awar, to say nothing of the disagreeablo idea often perrading the mind, that large numbers of these rermin are ranning orer the bread, leaving their droppings, \&c., to the great disgust of those "Tho aro obliged to sabsist on the biscuit.

In using the tanks, there will also be a great saving in the quantity and cost of bags, which, when stowed in bulk in the bread-room, rot very fast from damp, \&c., while tho tanks, if painted on the outside once a ycar, with whito cnamel paint, will last trenty or thirty years, for the internal coating of lime and sugar effectually prerents rust in that direction.

With regard to the foreign victualling stations, where biscuit is manufactured on the spot, if the climato is tropical and the bread is left in bags for any time after it is fully desiceated, nothing can prerent tho weeril and maggot from destroying it, but if put into tanks, of the desired construction, as soon as it is properly desicented, and then allowed to cool, it may be kept perfectly sweet for years, and can bo taken out from the lower scuttle into bags (a few bags of finer texture should, however, be used for this purpose, through the pores of which the weeril conld not enter), nnd the biscuit may then be conreycd on board the ship and immediatcly put into similar tanks fitted in the bread-room of the ship, and biscuit thus treated will assuredly keep in good condition as long as may bo required.

. With regard to thoso foreign stations whore the bread is not unde on the premises, bat simply stored, as receired from England, I would obscrve that large quantities of biscuit have been condemnel, from timo to time, at these places, from the ravages of weovils and maggots, produced from the eggs of the moth. From the raluable report of MIr. Rowsell, Director of Contracts, after personal inspection and from information he obtained on the spot, it appears that at Gibraltar, not long since, $390,000 \mathrm{lbs}$. of biscuit were condemned in five months, also 19,000 lbs. condemned on board "Hercules."

It has been sometimes customary to send out the biscuit to foreign stations in ordinars water tanks, but they haro failed to prevent the maggot from spoiling the bread, because they were not hermetically closed, also casks hare been used in many cases, these, from the shrinking of the stares, have either let in tho water which happened to fall on them (when all mildered together) or the weovils being very small, have got in through the joints and destroyed the whole contents, which occurred in the store at Jamaica not long ago, where 27,000 lbs. were condemned as unfit for hnman food.

To insure success in beeping a stock to meet tho wants of the shipping, it will be only necessary to hare a good supply of storetanks (similar to that which has been lately put into the Victunlling Yard at Hong Kong, from the "Victor Lmauucl," lato Hospital ship, spccially fitted for Ashantec War); and as to means of transit, the bread can be taken out from England in tanks so constructed as to hare shifting lids, the wholo size of the top, to be screwed up when filled with bread, and then hermetically closed br using putty in the joint, and afterward pasting orer it a strip of calico or Chinese paper. Theso tanks, which, when full, will contain 
20,000 to $30,000 \mathrm{lbs}$. of bread, can bo made to fit into each other. when cinpty, so that about trenty tanks may be brought home agaiu for re-filling, at a mere nominal cost, viz., the tonnage duo to the cubic contents of the largest tank, together with the bulk of the corers standing onc on the other. The cost, therefore, of returning the "empties," which has been the principal objection to sending the breal out in tanks, or in tin-lined cases, is reduced to a mere trifle, and the cost of sending it out rould be more than made up by the entire frecdom from condcmnations of bread, as herctofore, to say nothing of the comfort aud satisfaction of the Officers nnd crems of Her Mrajestr's ships, in not liaving to cat tho unrholosomo forcign-made bread, nor cren to be subject to make use of the otherwise good "service" bread when made loathsome by maggots and weerils.

It should also be obserred that the rarages of the weeril in the pro. rision-rooms of Her Jrajesty's ships, are not altogether confined to the biscuit, for all farinaccous articles of diet, such as flour, oatmeal, pearl-barloy, rice, \&c., also chocolnte, when stored in casks and open cases, are often attacked and destroyed, so that they are condemund and sold at considerable sacrifice; this may be entirely prerented by liaving the smaller tanks, in which these materials are stored in the issuing room, fitted on a similar principlo (although somerriat modificd) by haring the lower scuttle (which will require opening sereral times a day), fitted with a strong spring latch to close up tightly on a thin slip of india-rubber, so as not to require to be luted with putty in order to make it air-tight.

I hare thus exdenroured shortly to explain the mode which has, to a considerable extent, proved eflicacions in preserving the biscuit in Her MIajesty's Nary, as well ns to point out the furtl.er proposed method of supplying the varions foreign stations; and, I doubt not, if tho scheme be fairly worked, that in a short time the condemnation of biscrit in Her Majcstr's Nary (except from accidental causes, orer which there is no control) will be a thing rarcly known. 